\title{
Abdominal Variant of Lemierre's Syndrome in a Patient with Pancreatic Adenocarcinoma
}

\section{Pankreas Adenokarsinomlu Bir Hastada Abdominal Lemierre Sendromu}

\section{Yavuz FURUNCUOGLU $\odot$, Bala Basak OVEN $\odot$, Basak MERT $\odot$, Enis Cagatay YILMAZ $\odot$, Mustafa Kemal DEMIR $\odot$}

Ethics Committee Approval: Not Applicable.

Conflict of interest: The authors declare that they have no conflict of interest.

Funding: None.

Informed Consent: Informed consent was taken.
Cite as: Furuncuoglu Y, Oven BB, Mert B, Yilmaz EC, Demir MK. Abdominal variant of Lemierre's syndrome in a patient with pancreatic adenocarcinoma. Medeni Med J. 2021;36:58-62

\begin{abstract}
Lemierre's syndrome is an illness characterized by internal jugular vein thrombophlebitis related to infectious agents, primarily Fusobacterium necrophorum. These bacteria, residing in both the oropharynx and the gastrointestinal tract, may lead to pylephlebitis, a serious condition that could result in the development of hepatic abscesses. This manifestation of the disease is regarded as the abdominal variant of Lemierre's syndrome. Patients with gastrointestinal malignancies, especially those who undergo surgeries, are susceptible to the abdominal variant of Lemierre's syndrome. Timely diagnosis is required to avoid the life-threatening complications of the abdominal variant of Lemierre's syndrome. Diffusion-weighted magnetic resonance imaging (MRI) might be very useful in differentiating this disease from liver metastasis in patients with malignancies. Radiologists and clinicians need to be aware of this challenging condition to prevent misdiagnosis, since prompt treatment is often lifesaving.
\end{abstract}

Keywords: Lemierre's syndrome, thrombophlebitis, portal vein, liver abscess, pyogenic, pancreatic neoplasms

öz

Lemierre Sendromu, özellikle Fusobacterium necrophorum gibi enfeksiyöz ajanlarla ilişkili internal juguler ven tromboflebiti ile karakterize bir hastalıktır. Hem orofarenks, hem de gastrointestinal sistemde bulunan Fusobacterium necrophorum hepatik abselerle sonuçlanabilen ve ciddi bir durum olan pilefilebite neden olabilmektedir. Bu tabloya Lemierre sendromunun abdominal varyantı da denmektedir. Gastrointestinal malignitesi bulunan hastalar, özellikle cerrahi geçirenler, Lemierre sendromu abdominal varyantına daha duyarlı olmaktadır. Bu hastalığın hayatı tehdit eden komplikasyonlarının önüne geçmek için zamanında tanı gerekmektedir. Malignite hastalarında karaciğer metastazlarıyla ayrımında, difüzyon ağırlıklı manyetik rezonans görüntüleme (MRG) fayda sağlamaktadır. Erken tedavi hayat kurtarıcı olduğu için radyologlar ve klinisyenler yanlış tanının önüne geçmek adına bu zorlayıcı tanıyı da akıllarında bulundurmalılar.

Anahtar kelimeler: Lemierre sendromu, tromboflebit, portal ven, karaciğer absesi, piyojenik, pankreatik neoplazm
Received: 24 December 2020

Accepted: 5 February 2021

Online First: 26 March 2021

Corresponding Author: Y. Furuncuoğlu ORCID: 0000-0002-6716-5577

Bahçeşehir University

School of Medicine,

Department of Internal Medicine, Istanbul, Turkey

dryavuzf@yahoo.com

\section{B.B. Oven}

ORCID: 0000-0002-9921-4089

Bahçeşehir University

School of Medicine, Department of Medical Oncology, Istanbul, Turkey

B. Mert

ORCID: 0000-0001-7984-5214

E.C. Yilmaz

ORCID: 0000-0001-5301-3137

Bahçeşehir University School of Medicine, Istanbul, Turkey

M.K. Demir ORCID: 0000-0002-7023-6153

Bahçeșehir University School of Medicine, Department of Radiology, Istanbul, Turkey 


\section{INTRODUCTION}

Lemierre's syndrome is an oropharyngeal infection that secondarily causes internal jugular vein thrombophlebitis from which an infected thrombus can travel to infected distant areas, most commonly to the lungs ${ }^{1,2}$. This infection is caused by obligate anaerobe, Gram-negative, filamentous, and non-spore-forming bacteria, Fusobacterium necrophorum which usually belongs to the flora of oropharynx ${ }^{2}$. Rarely, these bacterial species can be the causative agent for pylephlebitis, which is defined as the development of thrombosis and inflammation of the portal vein that can lead to hepatic abscesses. This clinical picture is titled as "abdominal variant" of Lemierre's syndrome that can be due to Fusobacterium necrophorum or Fusobacterium nucleatum, which is also part of the flora residing in the gut ${ }^{3}$.
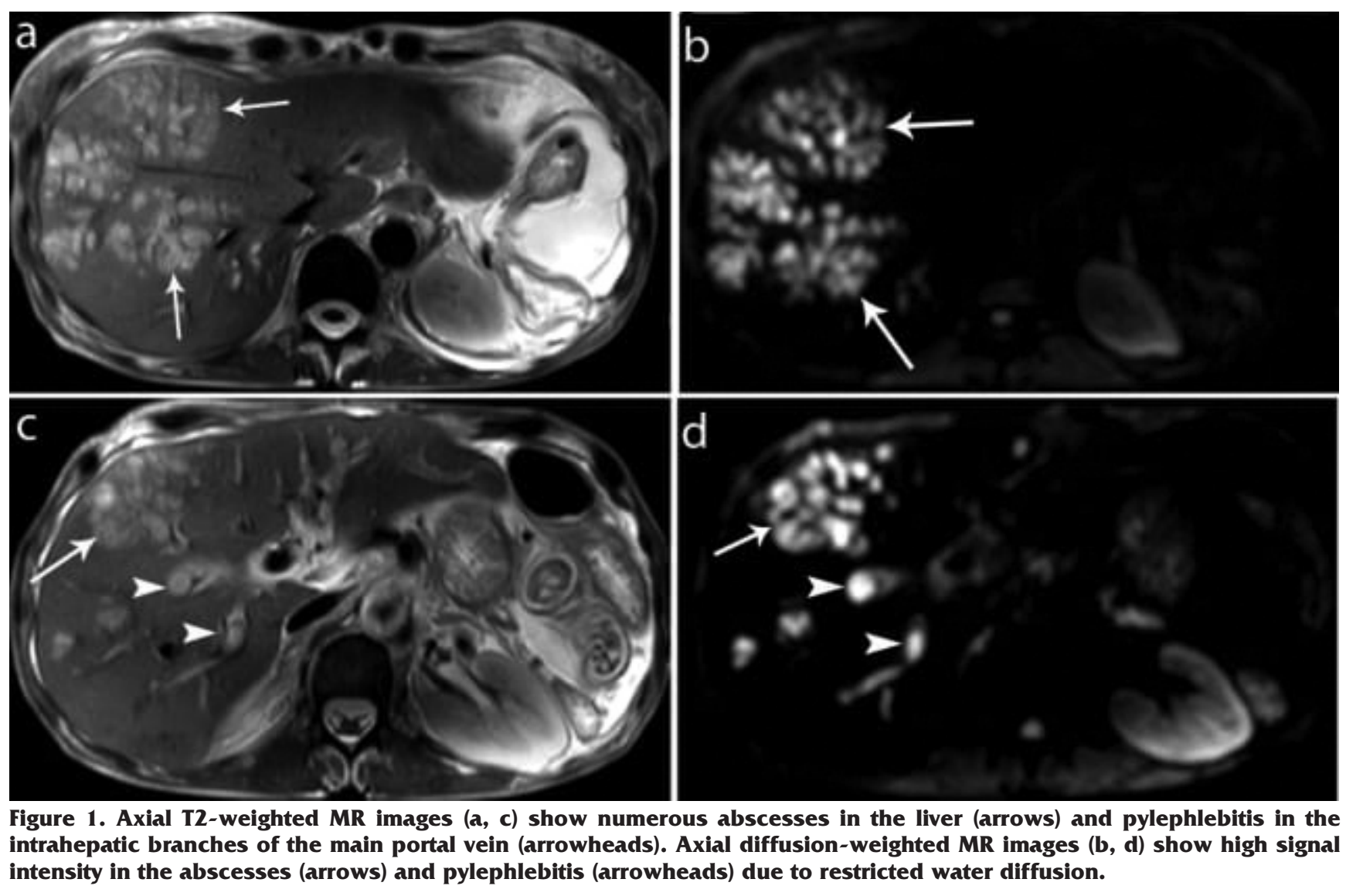

Figure 1. Axial T2-weighted MR images (a, c) show numerous abscesses in the liver (arrows) and pylephlebitis in the intrahepatic branches of the main portal vein (arrowheads). Axial diffusion-weighted MR images (b, d) show high signal intensity in the abscesses (arrows) and pylephlebitis (arrowheads) due to restricted water diffusion.

Herein, we present an extremely rare case of pylephlebitis of intrahepatic portal vein branches with multiple pyogenic hepatic abscesses - an abdominal Lemierre's syndrome - in a female patient previously diagnosed with pancreatic adenocarcinoma. Since as mentioned above, it is an unusual event, the diagnosis of this abdominal variant was very challenging and a high level of suspicion is required.

\section{CASE PRESENTATION}

A 54-year-old woman presented to our emergency department complaining of fever, chills, rigors, diarrhea, and upper abdominal discomfort. In July 2017, she received a diagnosis of pancreatic adenocarcinoma treated with a total pancreatectomy with regional lymph node dissection. The post-operative pathology report described the tumor as being a stage T2 N1 MO - grade 2 malignancy, and synchronous adjuvant chemo- 

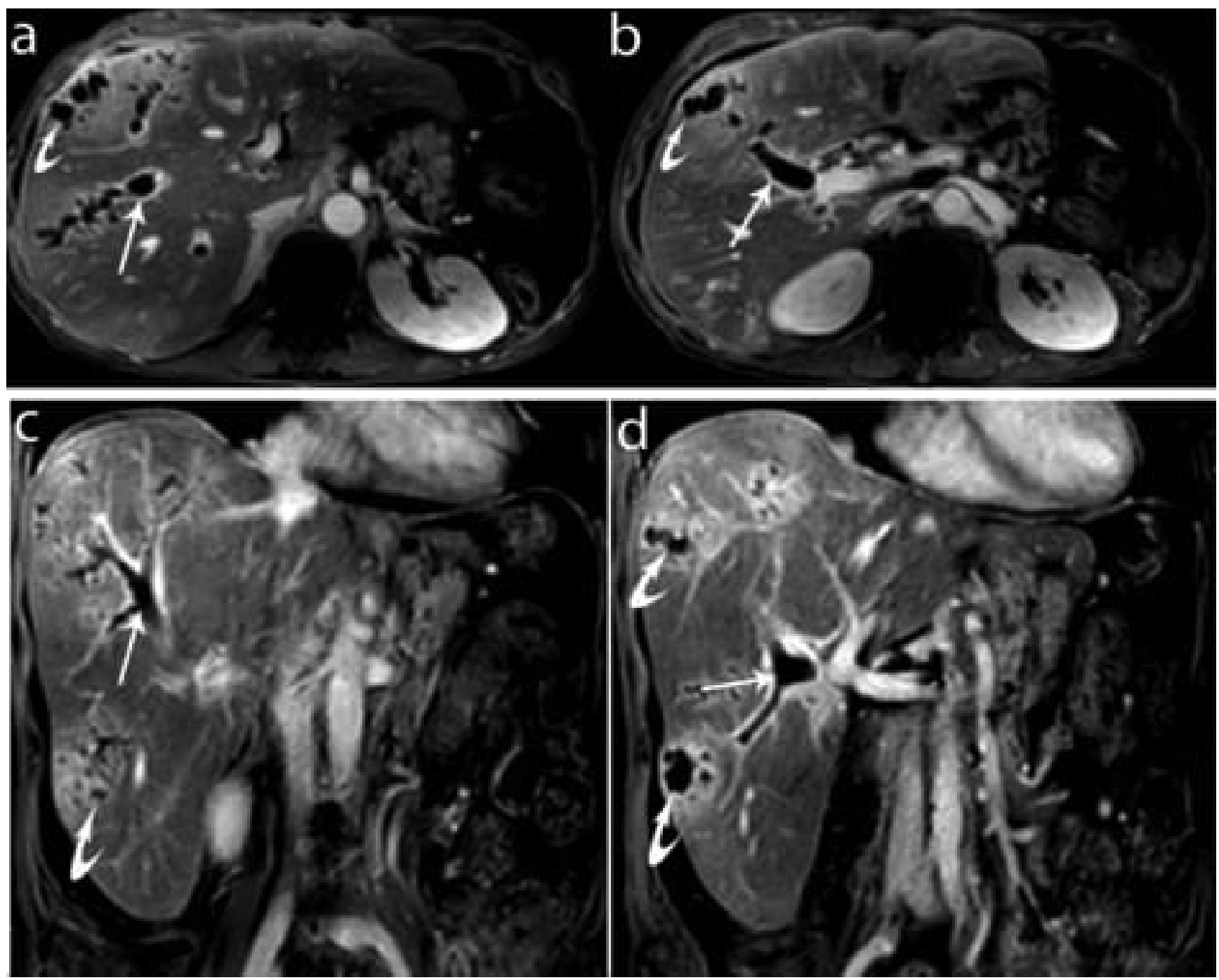

Figure 2. Axial (a, b) and coronal (c, d) contrast-enhanced T1-weighted MR images show multiple abscesses (curved arrows) and pylephlebitis in the intrahepatic branches of the main portal vein (arrows), which should not be confused as dilated intrahepatic bile ducts. Notice the normal appearance of main portal vein (arrowheads).

therapy and radiotherapy were performed. Adjuvant chemotherapy with gemcitabine plus cisplatin for 4 cycles were completed in November 2017. Her physical examination revealed right upper quadrant tenderness and ascites. Laboratory studies showed an increased C-reactive protein level of $107.67 \mathrm{mg} / \mathrm{L}$ (normal range, $0-8 \mathrm{mg} / \mathrm{L}$ ), leukocytosis with a white blood cell count of $11.31 \times 10^{\%} / \mathrm{L}$ (normal range, [4.2-10.2] $\times 10^{9} / \mathrm{L}$ ), low platelet count of $54 \times 10^{9} / \mathrm{L}$ (normal range, $\left.142-424 \times 10^{9} / \mathrm{L}\right)$. Liver enzyme levels were also elevated including aspartate aminotransferase (43 U/L: normal range $<32 \mathrm{U} / \mathrm{L}$ ), alkaline phos- phatase (192-32 U/L: normal range: 40-150 U/L), a gamma-glutamyl transpeptidase (172 U/L: normal range: 5-39 U/L), and lactate dehydrogenase (519 U/L: normal range: 125-243 U/L). Serum total and direct bilirubin levels were elevated, with values of $0.58 \mathrm{mg} / \mathrm{dL}$ (normal range: 0-0.5 $\mathrm{mg} / \mathrm{dL}$ ) and $1.60 \mathrm{mg} / \mathrm{dL}$ (normal range: 0.2-1.2 $\mathrm{mg} / \mathrm{dL}$ ), respectively. Tests for amebiasis, Clostridium difficile infections, hepatitis viruses werenegative, butblood cultures forFusobacterium necrophorum were positive. No invasive procedure was applied to the patient during this period. Meanwhile, the patient was not receiving any 
medical oncology treatment. MRI of the abdomen revealed multiple intrahepatic abscesses in addition to pylephlebitis in the intrahepatic branches of the portal vein (Figures 1-2). The patient was successfully treated with intravenous (IV) cefaperazone-sulbactam (2 gr/day) for 10 days and both her clinical and laboratory findings showed improvement. Follow-up MRI revealed the resolution of the liver abscesses and pylephlebitis. Furthermore, the ${ }^{18} \mathrm{~F}-\mathrm{FDG}$ PET/CT results showed absence of FDG uptake elsewhere in the body (Figure 3).

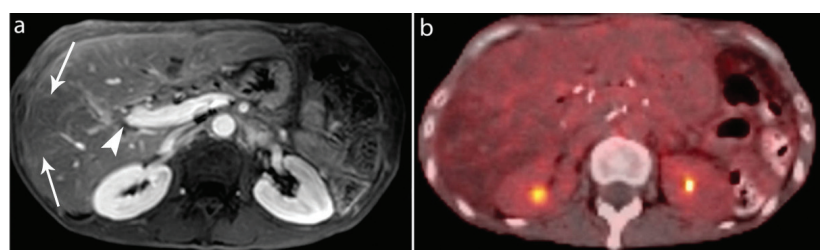

Figure 3. (a) Follow-up axial contrast-enhanced T1weighted MR image shows resolution of liver abscesses and improvement of pylephlebitis with a stricture in the portal branch of the right anterior liver segment (arrowhead), causing inhomogeneous enhancement of the hepatic parenchyma (arrows). (b) No FDG uptake was seen on 18F-FDG PET/CT.

This report does not contain any personal information that could lead to the identification of the patient and the personal details of the patient were excluded. A written informed consent from the patient is included in this article.

\section{DISCUSSION}

The classical presentation of Lemierre's syndrome consists of an oropharyngeal infection caused by Fusobacterium necrophorum that leads to a secondary purulent internal jugular vein thrombophlebitis and can usually result in infections in distant sites. Furthermore, Fusobacterium can also cause abdominal variant of Lemierre's syndrome which consists of pylephlebitis and hepatic abscesses in rare occasions. These cases of pylephlebitis usually happen as a result of intraabdominal infection or inflammation that drains into the portal venous system like appendicitis, diverticulitis, pancreatitis, or inflammatory bowel disease. It can also happen with gastrointestinal or genitourinary tumors ${ }^{4}$. Moreover, surgical procedures in areas drained by portal system can also increase the risk of infection, as presented in our case ${ }^{5}$. Pylephlebitis can become complicated and result in hepatic abscesses - abdominal Lemierre's syndrome, bowel ischemia, and portal hypertension ${ }^{3}$. It can also lead to sepsis, which is usually the most common cause of mortality in these patients ${ }^{6}$. Finally, there may be a link between chemotherapy-related immune suppression and enhanced bacterial virulence similar to the use of non-steroidal anti-inflammatory drugs and steroids in cancer patients ${ }^{7}$.

As mentioned above, an abdominal Lemierre's syndrome due to Fusobacterium is a rare occurrence. Other pathogens that cause this infection are Streptococcus viridans, Escherichia coli, and Bacteroides fragilis ${ }^{6}$. In most cases, patients are febrile and present with a right upper quadrant tenderness. Laboratory results usually show increased white blood cell count and abnormal liver function tests ${ }^{4}$.

For accurate diagnosis, blood cultures and radiological studies are essential. Computed tomography (CT) and ultrasonography are preferred imaging modalities. Contrast-enhanced CT is sensitive to visualize the thrombus in the portal system and the secondary hepatic abscesses ${ }^{3,5}$. In our case, we used MR imaging with diffusion-weighted sequence to help us accurately differentiate liver abscesses from liver metastases, since our patient was diagnosed with a pancreatic malignancy.

In spite of the limitations, diagnosis of bacteremia is still determined by blood culture. False positives are occasionally encountered in this method owing to contamination of the sample, which is confirmed by the presence of bacterial growth in the blood sample. Nevertheless, anaerobic gramnegative rods (e.g., Bacteroides spp. and Fusobacterium spp.), and Candida spp. are seldom responsible for contamination ${ }^{8}$. To be able to 
distinguish bacteremia from contamination, hints and methods like the identity of the organism, number of positive culture sets, number of positive bottles within a set, time to bacterial growth, quantity of growth, clinical and laboratory data, source of culture, and automated classification using information technology should be considered ${ }^{9}$. Since the clinical findings, imaging features, and hemoculture results were consistent in the presented case, no contamination was considered.

The treatment follows a stepwise approach. First, broad- spectrum antibiotics are given to the patients against the common pathogens until laboratory results prove that it is a Fusobacterium infection. Then, for Fusobacterium, third- generation cephalosporins with metronidazole or beta lactam/beta lactamase inhibitors or carbapenems are effective and should be given for four to six weeks ${ }^{4,6}$. In this case, beta lactam/beta-lactamase inhibitors treated the patient successfully. Anticoagulant therapy in these patients is still under investigation ${ }^{2-4}$.

\section{CONCLUSION}

The development of abdominal variant of Lemierre's syndrome in a patient with pancreatic adenocarcinoma during treatment or after surgery is a rare condition associated with a high mortality rate, if not diagnosed correctly. Therefore, being familiar with this syndrome and its imaging findings may lead to early recognition and treatment of the disease, which would result in a favorable prognosis.

\section{REFERENCES}

1. Walkty A, Embil J. Lemierre's Syndrome. N Engl J Med. 2019;380:e16. [CrossRef]

2. Moore JA, Rambally S. Fusobacterium nucleatum bacteremia presenting with portal vein thrombosis: an abdominal Lemierre syndrome? Am J Med. 2017;130:e255-6. [CrossRef]

3. Akhrass FA, Abdallah L, Berger S, Sartawi R. Gastrointestinal variant of Lemierre's syndrome complicating ruptured appendicitis. IDCases. 2015;2:72-6. [CrossRef]

4. Mellor TE, Mitchell N, Logan J. Lemierre's syndrome variant of the gut. BMJ Case Rep. 2017;2017:bcr2017221567. [CrossRef]

5. Tariq T, Badwal K, Wilt J, Boapimp P. Fusobacteriumassociated pylephlebitis complicated by hepatic abscess following roux-en-y gastric bypass surgery-gastrointestinal variant of Lemierre syndrome. Infect Dis Clin Pract. 2020;28:48-50. [CrossRef]

6. Handa S, Panthagani A, Buddhdev A. Abdominal Lemierre syndrome - an odd presentation of a rare entity. Journal of Scientific Innovation in Medicine. 2020;3:7. [CrossRef]

7. Al Duwaiki SM, Al Barwani AS, Taif S. Lemierre's syndrome. Oman Med J. 2018;33:523-6. [CrossRef]

8. Doern GV, Carroll KC, Diekema DJ, et al. Practical Guidance for clinical microbiology laboratories: a comprehensive update on the problem of blood culture contamination and a discussion of methods for addressing the problem. Clin Microbiol Rev. 2019;33:e0000919. [CrossRef]

9. Hall KK, Lyman JA. Updated review of blood culture contamination. Clin Microbiol Rev. 2006;19:788-802. [CrossRef] 